\section{Visión Electrónica \\ Más que un estado sólido}

http: revistas.udistrital.edu.co/ojs/index.php/visele/index

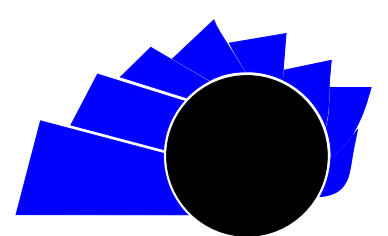

VISIÓN ELECTRÓNICA

A CURRENT VISION

\title{
State of the art on mobile apps: case study focused on university students in Bogotá, Colombia
}

\author{
Estado del arte sobre aplicaciones móviles: caso de estudio enfocado a \\ estudiantes universitarios en Bogotá, Colombia
}

\begin{abstract}
Fredy Alexander Manrique Suarez. ${ }^{1}$, Luis Carlos Velásquez Rodríguez. ${ }^{2}$, Giovanny Mauricio Tarazona Bermúdez. ${ }^{3}$
\end{abstract}

\section{INFORMACIÓN DEL ARTÍCULO}

Historia del artículo:

Enviado: 13/09/2016

Recibido: 02/04/2017

Aceptado: 22/08/2017

\section{Keywords:}

Market

Mobile applications

Smartphone

Success.

Open access

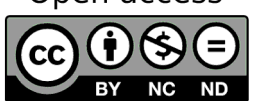

Palabras clave:

Mercado

Aplicaciones móviles

Smartphone

Éxito

\section{ABSTRACT}

A market study on mobile applications was conducted in Bogotá, Colombia. Surveys were applied to university students, the results were analyzed and the characteristics that users take into account when downloading and using mobile applications were frequently identified. In addition, the groups of mobile applications most used by users are determined, these were in order to provide valuable information to developers who create mobile applications which are more likely to achieve success in the market and help to solve the needs that day to day are presented by users. The results are contrasted with similar studies carried out in other countries, in order to compare their behavior and trends of users regarding downloading and usage of mobile applications in various countries.

\section{RESUMEN}

Se realizó un estudio de mercado sobre aplicaciones móviles en Bogotá, Colombia. Se aplicaron encuestas a estudiantes universitarios, se analizaron los resultados y se identificaron las características que los usuarios tienen en cuenta al momento de descargar y utilizar las aplicaciones móviles con frecuencia. Además, se determinan los grupos de aplicaciones móviles más usados por los usuarios, con el fin de brindar información valiosa a los desarrolladores para que creen aplicaciones móviles que tengan más posibilidades de lograr éxito en el mercado y ayuden a solucionar las necesidades que día a día presentan los usuarios. Los resultados obtenidos se contrastan con estudios similares realizados en otros países, con el fin de comparar el comportamiento y las tendencias de los usuarios con respecto a la descarga y uso de aplicaciones móviles en diversos países.

\footnotetext{
${ }^{1}$ BSc. In Industrial Engineering, Iberplast S.A.S; Bogotá, Colombia. E-mail: amanrique@iberplast.com.co.

${ }^{2}$ BSc. In Industrial Engineering, Avianca S.A.S, Bogotá, Colombia. Email: luis.velasquez.subavh@avianca.com.

${ }^{3} \mathrm{PhD}$. In Engineering Informatics. Universidad Pontificia de Salamanca, España. PhD. In Computer Systems for Internet, Universidad de Oviedo, España. Esp. In Software Engineering, Universidad Distrital Francisco José De Caldas, Colombia. Esp. In Computer Projects, Universidad Distrital Francisco José De Caldas, Colombia. Current position: Professor of the Faculty of Engineering, Universidad Distrital Francisco José de Caldas; Bogotá, Colombia. Email: gtarazona@udistrital.edu.co.
} 


\section{Introduction}

An app or application is a tool that gives a specific use on many topics to an electronic device. Apps ability to adapt to different types of devices allow them to expand their services or content for users [1].

Mobile applications were originally offered for general productivity and information retrieval, such as emails, calendars, contacts, stock exchanges and weather information [2]. However, there has been a rapid improvement and variability, due to the development of new technologies and partly to the fact that an increasing percentage of the population can now afford Smartphones or other devices capable of supporting these applications [3].

Mobile applications have become one of the fastest growing markets globally, according to the latest Gartner measurement during 2014, about 102 billion applications were downloaded worldwide, making a profit of 26 billion dollars [4].

It is estimated that nine out of ten Latin Americans use a mobile device on a regular basis, to reach a total of 406 million users, and in Latin America, 3 out of 7 people use a Smartphone. This means that in a region with more than 610 million inhabitants, more than 270 million people have a Smartphone [5]. Besides, the growing use of Smartphone has caused a huge increase of mobile applications. Additionally, mobile applications have become a daily requirement and users value their benefits [6].

Colombia is no stranger to this trend, according to a study carried out by the Ministry of Information and Communications Technology, in the country there are at least 92 formal companies dedicated to the development of mobile applications with an annual turnover of US \$ 425 million in sales. Samsung reported that Colombian people have downloaded an average of 17 applications on their phones and it is also mentioned that games, social networks and entertainment are the most frequent activities [7].

This dramatic growth has brought a new challenge for mobile users. This is, to find the most interesting and relevant applications of the hundreds of thousands that exist nowadays. A great number of industry solutions have emerged, which provides application recommendations and value-added services. These companies try to filter, rank and recommend the best applications to users [8].
Therefore, the current technological scenario, position service developers, as the new business force, in the next generation networks: Application Stores. This is why it is so important to unify methodologies and environments for the development of services, which is highly possible to facilitate the creation of these with a high quality, leading this development to success in an attractive and an efficient way [9]. Improving application detection and building better marketing tools is vital for the mobile application market and application stores to continue being successful [10].

\section{State of the Art}

There are several articles regarding to the development of applications for mobile scenarios, which have provided valuable information for developers to have more chances of success and to have a higher profitability in the market.

In [11], there are seven fundamental principles for the development of highly objective- oriented applications that are suggested such as: mobility, usability, relevance, ease of use, navigation fluency, user-oriented and customization. These principles can help make mobile services successful. According to [12], the sizes of the application and the category, as well as the number of associated comments are key factors that influence the success of applications.

This paper explains 5 key phases of successful mobile apps creation: Strategy, Design, Development, Marketing and Maintenance. Each phase is critical to the app's overall success and feeds into the next step of the process of product development for the app [13].

In $[14,15]$ the factors influencing quality of Mobile Apps are presented. These documents offer tips on how to avoid application failures and point out that the number of failed applications is growing because mobile application developers are not adopting a standard lifecycle development for application development. According to [16], the chance of an app to succeed late in its lifecycle is low if it had not taken off within the first few months of its launch. Further, price cuts and frequent updates could be complementary strategies for developers, but they have varying effects depending on the age of apps and quality perceptions by users. Additionally, [17], Online mobile applications are widely used in many critical areas such as online shopping, ticket booking, e-commerce, etc. The quality of these applications depends on related network factors that 
may affect the normal operation of the application.

This research examines key characteristics of the application and the vendor that influence success in an app store market. The authors explain some application attributes that lead to a higher demand from potential users and increase the longevity of applications [18].

The use of user reviews published in mobile app stores is pointed out as useful information for developers. The analysis of these comments have contributed to extract the requirements of the user for the construction of new applications or to improve the existing ones [19-21].

Another work encompasses business models for the mobile application market from a developer's point of view, it emphasizes on the elements of the business model of a mobile application developer [22]. In [23], the authors have described the implications that different market and technology trends have on the mobile application development market. There are many new opportunities for developers to create, distribute, and generate significant revenues with the emerging mobile application portals.

This work carries out one of the largest surveys to date of app users across the world; Data were collected from more than 15 countries, in order to identify country differences in mobile app user behavior [24]. A research study on mobile marketing was realized at the University of La Rioja in Spain. It analyzed Spanish users behavior regarding the characteristics and attributes they had in mind when using mobile applications [25].

Another paper describes the development of mobile phone applications for the Indian market - small applications for a huge market that has its own challenges [26]. During 2016, India grew massively, surpassing the U.S. as the No. 1 country by Google Play downloads. India grew from more than 3.5 billion downloads in 2015 to more than 6 billion in 2016 [27].

Research studies conducted at Universities in Mexico have analyzed the influence of Smartphone on students' performance and their use within their academic development. [28, 29]

Companies are now adopting mobile technologies towards numerous applications to increase their operational efficiency, to improve their responsiveness and competitiveness, to capitalize on the mobile revolution, and to meet new customer demands [30]. Enterprises are now reaching a diverse array of customers through the use of web and mobile applications [31]. By
2018, Gartner expects that the 200 largest companies in the world "exploit smart applications and use all the big data and analysis tools to redefine their offerings" [32].

In this paper the authors have examined the production and distribution of mobile apps as a source of growth and job creation for Colombia. They found that Colombia had over 83,100 App Economy jobs as of September 2016. In addition, they explain the potential and obstacles that the mobile applications sector has had in the country in the long term [33].

\section{Methodology}

To collect information, a database of questions was elaborated. They would help to answer what the characteristics and functionalities mobile applications must have and which ones, users value the most, 17 closed questions were selected and the survey was then created in Google Forms tool.

The survey focused on university students in the city of Bogota D.C, Colombia. People from different universities were randomly selected from various academic programs; they all agreed to complete the survey. The questionnaire was applied in two ways: the first was that students were requested their e-mail address and then the survey link was sent to them for later processing. The second one was face-to-face, students were provided with a Tablet in which the survey was already in place and then they were asked to respond immediately.

After collecting the information for 19 days, our team researchers proceed to do the data consolidation and the subsequent analysis of the results.

\subsection{Data Sheet (Table 1)}

Table 1: Technical Data Sheet of the Survey.

\begin{tabular}{|c|c|}
\hline Population & University Population \\
\hline Sampling Procedure & $\begin{array}{l}\text { University students were randomly selected from } \\
\text { different universities in Bogotá, Colombia }\end{array}$ \\
\hline Data collection & $\begin{array}{l}\text { Personal survey carried out via Google Drive } \\
\text { Form, sent to email or applied in person. }\end{array}$ \\
\hline Scope & Bogota, Colombia. \\
\hline Sampling & 220 \\
\hline Valid Surveys & 148 \\
\hline Sample Error and Confidence Level & $+/-8,05 \%\left(^{*}\right) ; 95 \%(\mathrm{k}=1,96)$ \\
\hline Maximum variance allowed & $\mathrm{p}=\mathrm{q}=50 \%$ \\
\hline Fieldwork Date & October $10^{t h}-19^{t h}, 2016$ \\
\hline \multicolumn{2}{|l|}{ Sampling Characteristics } \\
\hline Gender & $52,02 \%$ Female and $47,97 \%$ Male \\
\hline Age & $\begin{array}{c}441.35 \% \text { between the ages of } 35 \text { and } 44 ; \\
3418.92 \% \text { between the ages of } 26 \text { and } 34 \text {; } \\
\text { and } 2579.73 \% \text { under } 25\end{array}$ \\
\hline
\end{tabular}

Source: own. 


\section{Analysis of the Results}

\subsection{Type of Mobile Phone}

The number of Smartphone users in the world is rapidly increasing. In Europe, 78 out of 100 people have a Smartphone [34]. This figure is very similar to that found in the present study; of the people surveyed about $94.59 \%$ use a Smartphone. This means that in Colombia, like in Europe, most of its inhabitants have a Smartphone. But these figures contrast with the picture in Africa where many cannot afford to buy expensive Smartphones. Only "low-cost function phonesçan be afforded. Data from BuzzCity show that in 2013, between 85 and 90 percent of people in Kenya and Nigeria used "Simple Feature Phones " [35].

\section{2. $O S$}

In the United States the use of operating systems is balanced, $52.8 \%$ of users use Android, followed by $43.6 \%$ that run iOS [36]. In Latin America, the predominant operating system is Android with $78 \%$ of Smartphone users [37]. In the present study, the operating systems that users have can be seen in the following chart (Figure 1):

Figure 1: OS run by the users of the present study.

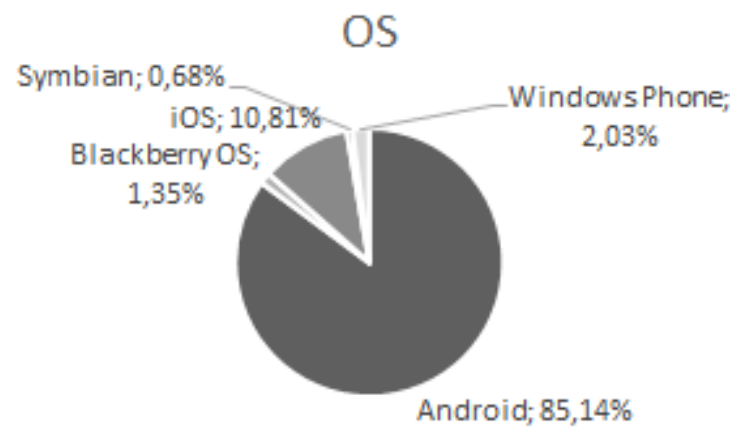

Source: own.

\subsection{Mobile Applications Download Frequency}

The behavior in the United States regarding the frequency of downloads of mobile applications, according to a report of mobile applications made by Comscore, shows that $49 \%$ of people who use a Smartphone download in average zero mobile applications per month. Out of the other $51 \%$ of users that do download some mobile application per month, it is concluded that: $13 \%$ of them download one application, $11 \%$ two apps, $8 \%$ three apps, only $6 \%$ download more than eight apps.
Thus, the average download is 3.5 apps per month (Figure 2) [38]

Figure 2: Mobile application download frequency.

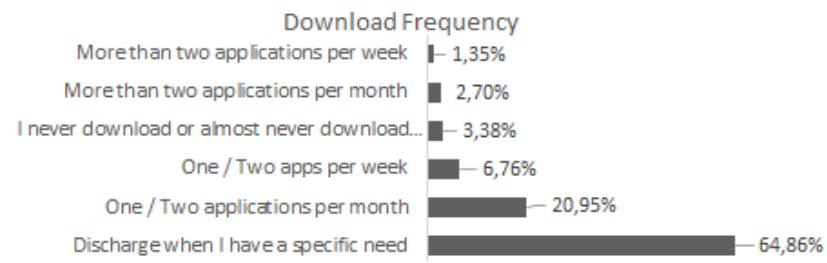

Source: own.

Comparing this to the results of other countries, the download frequency of mobile applications of the users of the present study is low; users only download apps when having a specific need. This can be explained by the fact that most of the devices have the most commonly used applications preinstalled.

\subsection{Mobile Applications vs. Browser}

The enterprise Millward Brown in the United States analyzed the 30 most visited internet domains and found out that visits generated by both mobile and browser applications were very similar, $59 \%$ entered through the browser, while $60 \%$ entered through a mobile application [39]. In Latin America, $64 \%$ of users prefer to do a task digitally if they have the opportunity. $36 \%$ of users go online more frequently from their mobile than from their PC. $73 \%$ of users first look for information on the internet before using other sources [37]. A very similar situation occurs in the present study, since $52 \%$ of the respondents prefer to have a mobile application to perform some activity in a digital way, while $45 \%$ prefer to do it through the browser.

\subsection{Connection Time for Mobile Applications}

Time spent in apps grew more than 20 percent to nearly 900 billion hours in 2016, according to App Annie's year-end report. U.S. time spent in apps grew more than 25 percent [27]. In Spain, the usage time of mobile applications is 3 hours on average [34].

The following chart displays the time that people surveyed in Bogota dedicate daily to use the mobile applications (Figure 3): 
Figure 3: Amount of daily time using mobile applications.

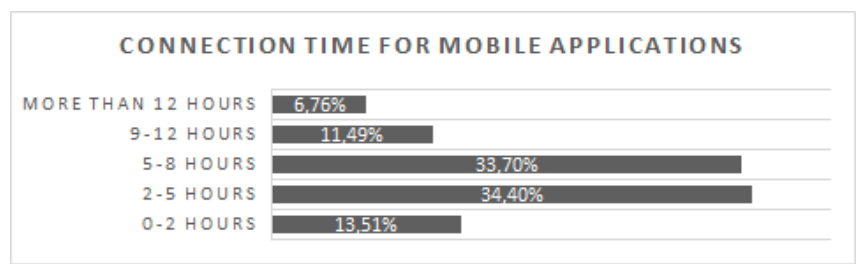

Source: own.

It is observed that $68.3 \%$ of users remain online from 2 to 8 hours to mobile applications. Approximately one-third of the respondents have an online time very similar to the ones in Spanish.

\subsection{Time spent on different categories of mobile applications}

The usage time by categories of mobile applications varies depending on the country; for example, in Germany the category in which users spend most of the time is games, with $34 \%$, followed by messaging and social networks with $22 \%$. The behavior is similar in Italy, with $26 \%$ of the time spent in games and $19 \%$ in messaging and social networks. With regard to France, the most popular categories are messaging and social networks with $40 \%$, followed by games with $23 \%$. While United Kingdom's behavior is very similar to France's, with $41 \%$ of the time spent on messaging and social networks, followed by games with $22 \%$ [39].

In Latin America, according to a study conducted by Flurry, $44 \%$ of the time spent to use mobile applications is for productivity, followed by sports $(19 \%)$, another $17 \%$ of the time is occupied in social network applications and messaging, $12 \%$ is spent on games, $4 \%$ in shopping and lifestyle applications, $3 \%$ in entertainment applications and $1 \%$ of the time in health applications (Figure 4) [40].

Figure 4: Use of mobile applications by category.

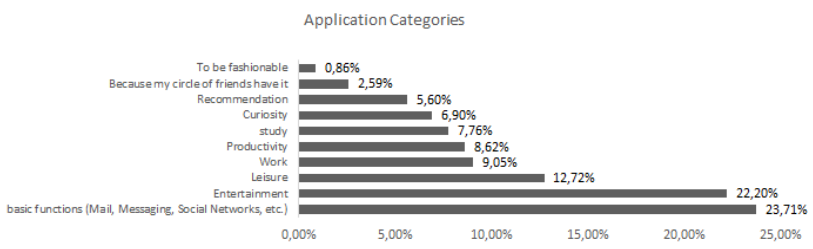

Source: own.
With respect to the respondents in the present study, it was observed that $23.71 \%$ of users use mobile applications for specific and basic functions (Mail, Messaging, Social Networks, etc.), $22.2 \%$ use them for Entertainment (games and others). So the behavior to this respect is similar both in Colombia and in European countries; specific functions, messaging, social networks and games, are the most commonly used categories.

\subsection{Most valued attributes of mobile applications}

In the survey of the present study, users were asked to rate a set of items from 1 to 5, 1 being strongly disagree and 5 being strongly agree. An average of all the ratings given by users to each of the items was performed. The following are the attributes that had the highest rankings in the assessment (Figure 5):

Figure 5: Attributes most valued by users in a mobile application.

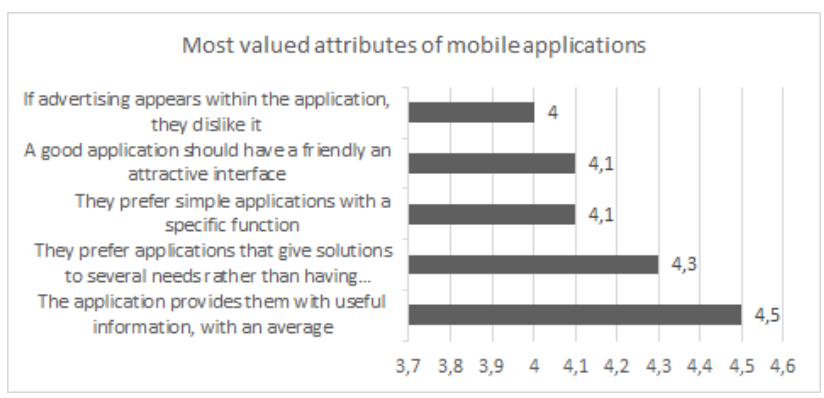

Source: own.

\subsection{The most popular apps}

In Latin America, WhatsApp, YouTube and Facebook are the most widely used applications on mobile devices, according to a study conducted by IMS Mobile comScore, Inc. and IMS Internet Media Services (IMS) (Figure 6) [41].

Figure 6: Most used applications in Latin America.

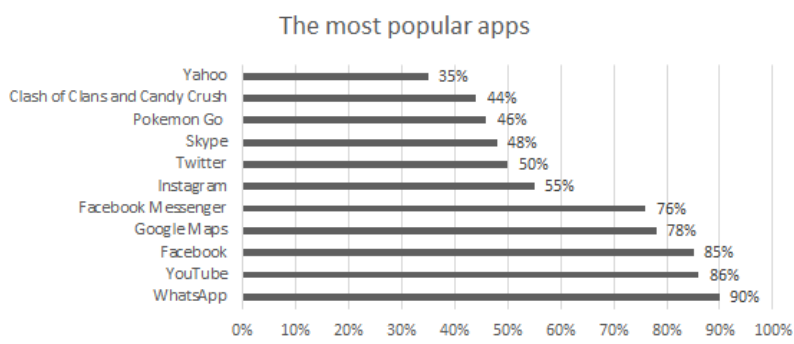

Source: own. 
Social networks in Latin America lead the consumption, especially among people between 25 and 34, who mainly use WhatsApp, Twitter and Facebook. Likewise, it is possible to identify that applications such as Google Maps have $78 \%$ of popularity, being ranked in fourth position and followed by Facebook Messenger and Instagram [41].

A survey by SurveyMonkey Intelligence has revealed the 30 most downloaded and most popular applications in the first 7 months of 2016, in the iOS American store and in Android application store. The five most downloaded applications are: Messenger, Snapchat, Facebook, Instagram and Color Switch, while the five most popular applications were Facebook, YouTube, Messenger, Google Maps and Play Store. The report found that the most downloaded applications are not the most popular ones. The report also indicated that 40 percent of the most popular applications come pre-installed into the operating system, highlighting the importance of Android and iOS in Google and Apple, and giving some insight into Facebook's continued desire to have this scenario under control [42].

In this study, it can be observed that almost all users: $99.3 \%$, have WhatsApp on their mobile devices, and $92.6 \%$ have Facebook, Facebook Messenger is another application that most respondents have and use; $82.4 \%$. Other applications that are very popular are: Instagram; $61,5 \%$. Google Drive; $60,8 \%$ and Outlook; with $56,8 \%$. According to the results, the trend in Latin America and the World is being followed in Bogotá, since instant messaging applications and social networks are the ones most frequently used by users on their Smartphone.

Instant messaging is one of the fastest growing categories in the world. According to eMarketer, in 2016 more than 1.610 million people have installed an application of this type on their Smartphone. This figure will continue to grow at the rate of 200 million users per year, exceeding 2 billion, which will represent $80 \%$ of Smartphone users by 2018 [43].

In the present study conducted in Bogota, respondents were asked if the mobile applications they use the most, already had them pre-installed on their Smartphone and the results indicate that $64 \%$ of the respondents already had them pre-installed.

\subsection{Productivity Mobile Applications}

In the United States the most downloaded productivity-free applications for Android system were: Super-Bright LED Flashlight, Clean My Android,
Google Docs, Trash Manager Clean Cache, Brightest Flashlight-Multi LED [44], and in Germany, the most downloaded FREE applications were: Super-Bright LED Flashlight, Adobe Acrobat Reader, Clean My Android, Microsoft Outlook, Microsoft Word [45].

The university students in Bogota were asked which of the following productivity mobile applications they had in their Smartphone, the results were (Figure 7):

Figure 7: Use of productivity applications.

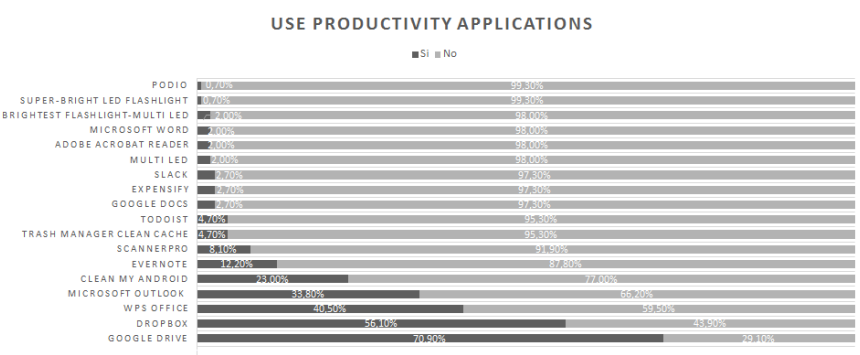

Source: own.

It is observed that in the Android operating system the most downloaded productivity applications in the United States and Germany, are not the most downloaded as the university students in Bogotá, where the most downloaded apps are Google Drive and Dropbox. It can be concluded that these users barely download or use productivity applications, except for cloud storage applications.

\subsection{Purchase of Mobile Applications}

This research examines the relationship between personality traits and mobile application purchasing tendencies, specifically the tendency to pay for apps when free alternatives are available (Mobile App Payment), and the tendency to make In-App Purchases [46].

In [47] the factors behind application downloads in three operating systems in the Netherlands are explored. Variables such as price, monetization and category are analyzed to see which aspects influence downloading of users in the Netherlands. The research found that people would rather try a full application (trial periods), than downloading a free application and pay for additional features. People are only willing to pay for an application when it has received many positive reviews from other users.

In the case of China that has proved to be a very promising country for developers, it is one of the most 
revenue generates, and will generate in the medium and long term [48]. A methodology used in this country called in-app", basically consists of paying for an app if you want to use all the functions, that is, only part of the application is offered for free [49].

Worldwide this seems to be a very effective way to generate income. It would be a very interesting strategy to test this model, that has worked in Europe, the US and Asia, in Colombia, as a Test Period, since users are more likely to buy apps after they have been invited to test the functionalities of the mobile applications.

This paper examines the effect of the freemium strategy on Google Play. This strategy, is positively associated with increased sales volume and revenue of the paid apps. It suggests that although offering a free version is a viable way to improve the visibility of a mobile app, revenue is largely determined by product quality, not product visibility [50].

In this study conducted in Bogotá, only $16.89 \%$ of users have purchased or are willing to pay for a mobile application.

\section{Conclusions}

After analyzing the results obtained in the survey, these were compared with related mobile applications in other countries.

Users surveyed prefer to download and to use mobile applications that solving specific problems; they download them when they have a specific need, so the download frequency of mobile applications is low. This trend is similar in the United States, where according to the report done by Comscore, $49 \%$ of people who use a Smartphone download an average of zero mobile applications per month. This may explain why most of the devices are pre- installed with the most common applications. It can be explained by the fact that most of the devices have the most commonly used applications were pre-installed.

On the one hand, satisfaction of a need, usability, ease of use, attractive graphic design, advertising-free. They are the most valued attributes of the mobile applications by the users surveyed. They are similar to the most valued attributes in Spain, according to the study carried out at the University of Rioja. "Mobile application users can obtain maximum gratification from "relaxing and relieving stress", they don't feel gratification from "learning different languages", "being personal assistant" and "obtaining real-time information", obviously showing that entertainment effect of mobile applications has achieved user's expectation" [51].

On the other hand, in [24], the results indicate that country-specific differences exist in almost all categories: users from the United Kingdom are most forgetful about their apps and most influenced by price, users from Japan prefer not to rate apps, users from China are more likely to select the first app on the list more than any other, users from Mexico think that paid apps have more features, and users from Germany and Russia are more likely to download reference apps.

The most frequently used mobile application categories are: Instant Messaging, Social Networks and Gaming. This is the same behavior as in European countries like Germany, France, Italy, UK, among others. But it differs from Latin America, where productivity and sports applications are the most popular among users.

One of the most common mistakes for the mobile application developers is not identifying the needs in the market in order to create a mobile application that meets those needs and that takes into account the characteristics that users value most, this means, they do not do a previous market study.

Most users are not willing to pay for a mobile application; this is because they do not truly know if the application will give them the functionality they need. The methodology in-appüsed in China could be applied - give a trial version to the user to interact with the application and evaluate if it is worth buying.

\section{Future Research Areas}

As a future research area, it would be interesting to carry out the same study with a larger population sample and it can be at a national level and to make a great segmentation including educational level, age, income, etc. with the purpose of being able to have much more detailed and information about users preferences and behaviors of each group in the country.

\section{Acknowledgments}

To the research group GICOECOL

\section{References}

[1] "Informe APPS Septiembre 2012 - The App Date España." january 13th 2017 [Online]. 
Available: http://www.theappdate.es/ informe-apps-septiembre-2012/

[2] B. Senthil Kumar, R. Ravi, P. Dhanalakshmi, S. Kirubakaran, and K. Maheswari, "Classification of Mobile Applications with rich information," in 2015 International Conference on Soft-Computing and Networks Security (ICSNS), 2015, pp. 1-7, https : //doi.org/10.1109/ICSNS. 2015.7292427

[3] I. San Mauro Martín, M. González Fernández, and L. Collado Yurrita, "Aplicaciones móviles en nutrición, dietética y hábitos saludables: análisis y consecuencia de una tendencia a la alza," Nutr. Hosp., vol. 30, no. 1, pp. 15-24, 2014.

[4] "Desarrollo de apps en Colombia: ¿Cuál es la oportunidad para el desarrollador y la empresa? - M2M - Marketing to marketing." january 13th 2017 [Online]. Available: http://m2m.com.co/actualidad/ desarrollo-de-apps-en-colombia-cual-es-la\ -oportunidad-para-el-desarrollador-y-la-em\ presa/

[5] "La mayor oportunidad para un Desarrollador Móvil en América Latina - Next U." january 13th 2017 [Online]. Available: http://www.nextu.com/blog/ la-mayor-oportunidad-para-un-desarrollador -movil-en-america-latina/

[6] P. Hazarika, Rahul Raj CP, and S. Tolety, "Recommendations for Webview Based Mobile Applications on Android," in 2014 IEEE International Conference on Advanced Communications, Control and Computing Technologies, 2014, pp. 1589-1592. https: //doi.org/10.1109/ICACCCT.2014.7019375

[7] "El auge de las apps — El Espectador.com." january 13th 2017 [Online]. Available: http: //www.elespectador.com/tecnologia/ el-auge-de-apps-articulo-481445

[8] A. Karatzoglou, L. Baltrunas, K. Church, and M. Böhmer, "Climbing the app wall: enabling mobile app discovery through context-aware recommendations," in Proceedings of the 21st ACM international conference on Information and knowledge management - CIKM '12, 2012, p. 2527. https://doi.org/10.1145/2396761.2398683

[9] M. C. G. Mantilla, L. L. C. Ariza, and B. M. Delgado, "Metodología para el desarrollo de aplicaciones móviles," Revista Tecnura, vol. 18, no. 40, pp. 20-35, 2014. https://doi.org/10.14483/ udistrital.jour.tecnura.2014.2.a02
[10] B. Erman, A. Inan, R. Nagarajan, and H. Uzunalioglu, "Mobile applications discovery: A subscriber-centric approach," Bell Labs Tech. J., vol. 15, no. 4, pp. 135-148, Mar. 2011. https : //doi.org/ $10.1002 / \mathrm{bltj} .20477$

[11] H. Oinas-Kukkonen and V. Kurkela, "Developing Succesful Mobile Applications," in Proceedings of: International Conference on Computer Science and Technology (IASTED), 2003, pp. 50-54.

[12] L. Guerrouj and O. Baysal, "Investigating the android apps' success: An empirical study," in 2016 IEEE 24th International Conference on Program Comprehension (ICPC), 2016, pp. 1-4. https:// doi.org/10.1109/ICPC . 2016.7503724

[13] " 5 Key Phases In Creating a Successful Mobile App," New Reli., pp. 1-12, 2013.

[14] V. N. Inukollu, D. D. Keshamoni, T. Kang, and M. Inukollu, "Factors Influencing Quality of Mobile Apps: Role of Mobile App Development Life Cycle," Int. J. Softw. Eng. Appl., vol. 5, no. 5, 2014.

[15] A. Zamfiroiu, "Factors Influencing the Quality of Mobile Applications," Inform. Econ., vol. 18, no. 1, pp. 131-138, 2014. https://doi.org/10.12948/ issn14531305/18.1.2014.12

[16] S. Kajanan, N. Pervin, N. Ramasubbu, K. Dutta, and A. Datta, "Takeoff and Sustained Success of Apps in Hypercompetitive Mobile Platform Ecosystems: An Empirical Analysis," in Thirty Third International Conference on Information Systems., 2012.

[17] V. S. Sundara Rajan, A. Malini, and K. Sundarakantham, "Performance evaluation of online mobile application using Test My App," in 2014 IEEE International Conference on Advanced Communications, Control and Computing Technologies, 2014, pp. 1148-1152. https: //doi.org/10.1109/ICACCCT . 2014.7019277

[18] G. Lee and T. S. Raghu, "Determinants of Mobile Apps' Success: Evidence from the App Store Market," J. Manag. Inf. Syst., vol. 31, no. 2, pp. 133-170, Oct. 2014. https://doi.org/10.2753/ MIS0742-1222310206

[19] N. M. Rizk, A. Ebada, and E. S. Nasr, "Investigating mobile applications' requirements evolution through sentiment analysis of users' reviews," in 2015 11th International Computer Engineering Conference (ICENCO), 2015, pp. 123-130. https://doi.org/10.1109/ICENCO. 2015. 7416336 
[20] D. Pagano and W. Maalej, "User feedback in the appstore: An empirical study," in 2013 21st IEEE International Requirements Engineering Conference (RE), 2013, pp. 125-134. https://doi.org/10. 1109/RE.2013.6636712

[21] C. Iacob and R. Harrison, "Retrieving and analyzing mobile apps feature requests from online reviews," in 2013 10th Working Conference on Mining Software Repositories (MSR), 2013, pp. 41-44. https://doi.org/10.1109/MSR.2013.6624001

[22] F. Vannieuwenborg, L. Mainil, S. Verbrugge, M. Pickavet, and D. Colle, "Business models for the mobile application market from a developer's viewpoint," in 2012 16th International Conference on Intelligence in Next Generation Networks, 2012, pp. 171-178. https://doi.org/10.1109/ ICIN. 2012.6376022

[23] A. Holzer and J. Ondrus, "Mobile application market: A developer's perspective," Telemat. Informatics, vol. 28, no. 1, pp. 22-31, Feb. 2011. https://doi.org/10.1016/j.tele.2010.05.006

[24] S. L. Lim, P. J. Bentley, N. Kanakam, F. Ishikawa, and S. Honiden, "Investigating Country Differences in Mobile App User Behavior and Challenges for Software Engineering," IEEE Trans. Softw. Eng., vol. 41, no. 1, pp. 40-64, Jan. 2015. https://doi.org/ 10.1109/TSE. 2014.2360674

[25] B. M. Barrio, "Marketing móvil basado en aplicaciones" Universidad de la Rioja, 2013. pp. 1-48.

[26] R. D. Sadafule, "Mobile app development for the Indian market," IEEE Softw., vol. 31, no. 3, pp. 17-20, May 2014. https://doi.org/10.1109/MS. 2014.67

[27] "App Annie: Worldwide app downloads grew $15 \%$ and revenue soared $40 \%$ in 2016." January 12th 2017, [Online]. Available: http://venturebeat.com/2017/01/17/

app-annie-worldwide-app-downloads-grew-15and-revenue-soared-40-in-2016/

[28] B. Herrera Sánchez, G. A. Diez Irizar, and M. de los Á. Buenabad Arias, "El uso de los teléfonos móviles, las aplicaciones y su rendimiento académico en los alumnos de la DES DACI," Rev. Iberoam. para la Investig. y el Desarro. Educ., vol. 12, pp. 1-18, 2014.

[29] A. Linares Pe-aloza and M. L. Quintero Soto, "La Actitud de los Adolescentes Universitarios ante el Uso y Aplicación del Celular e Internet, en su Desarrollo Académico," Rev. Digit. Univ., vol. 13, pp. 3-22, 2012.
[30] B. Unhelkar and S. Murugesan, "The Enterprise Mobile Applications Development Framework," IT Prof., vol. 12, no. 3, pp. 33-39, May 2010. https: //doi.org/10.1109/MITP. 2010.45

[31] D. Nyambo, Z. O. Yonah, and C. Tarimo, "Security frameworks in the converged web and mobile applications: A review," in Proceedings of the 2nd Pan African International Conference on Science, Computing and Telecommunications (PACT 2014), 2014, pp. 29-34. https://doi.org/10.1109/SCAT . 2014.7055131

[32] “¿Cuáles son las tendencias tecnológicas que marcarán 2017? - BBC Mundo.” January 12th 2017, [Online]. Available: http://www.bbc.com/mundo/ noticias-38343954

[33] M. Di Ionno and M. Mandel, "Tracking Colombia's App Economy," Progress. Policy Inst., p. 1, 2016.

[34] Ditrendia Digit. Mark. Trends "Informe ditrendia 2016: Mobile en Espa-a y en el Mundo" January 12th 2017, [Online]. Available: http://www.amic.media/ media/files/file_352_1050.pdf

[35] S. Murugesan, "Mobile Apps in Africa," IT Prof., vol. 15 , no. 5, pp. 8-11, Sep. 2013. https://doi. org/10.1109/MITP. 2013.83

[36] "comScore Reports January 2016 U.S. Smartphone Subscriber Market Share - comScore, Inc," comScore, december 21th 2016. [Online]. Available: https://www . comscore.com/Insights/Rankings/ comScore-Reports-January-2016-US-Smartphone। -Subscriber-Market-Share

[37] M. Guzmán Delgado, "El imperio de Android crece en Latinoamérica," Andro4all, december 21th 2016. [Online]. Available: https://andro4all.com/2016/ 05/crecimiento-android-latinoamerica

[38] R. A. Gómez Sustacha, "El $49 \%$ de los estadounidenses ya no descarga apps, según Comscore," Marketing 4 Ecommerce - Tu revista de marketing online para e-commerce, december 21th 2016. [Online]. Available: http://marketing4ecommerce.net/ el-49-de-las-personas-no-descarga-apps/

[39] N. Hollis, "Browser versus App, which wins with consumers and when?," december 21th 2016. [Online]. Available: http://www. millwardbrown.com/global-navigation/ blogs/post/mb-blog/2015/11/02/ browser-versus-app-which-wins-with-consumers- $\backslash$ and-when 
[40] R. Alonso Rebolledo, " 4 datos del uso de aplicaciones en América Latina," El Economista, december 21th 2016. [Online]. Available: http: //eleconomista.com.mx/tecnociencia/2016/08/ 25/4-datos-uso-aplicaciones-america-\latina

[41] "Las 10 aplicaciones más utilizadas en América Latina," Computerworld Colombia, december 21th 2016. [Online]. Available: http://computerworld.co/ las-10-aplicaciones-mas-utilizadas-americal -latina/

[42] K. Morán, "Estas son las aplicaciones más descargadas en Estados Unidos," Clases de Periodismo, december 21th 2016. [Online]. Available: http://www . clasesdeperiodismo.com/2016/07/30/ estas-son-las-aplicaciones-mas-descargadas $\backslash$ -en-estados-unidos/

[43] T. Franceschin, “¿Cómo hizo Line para convertirse en una de las apps más rentablesl?," Vrainz, december 21th 2016. [Online]. Available: http://www.vrainz.com/ como-hizo-line-para-convertirse-en-una-delas-apps-mas-rentables-a-nivel-mundial/

[44] "Top Grossing Apps and Download Statistics Google Play," App Annie, december 21th 2016. [Online]. Available: https://www appannie. com/apps/google-play/top/united-states/ application/productivity/

[45] "Top Grossing Apps and Download Statistics Google Play," App Annie, december 21th 2016. [Online]. Available: https://www.appannie.com/ apps/google-play/top/germany/application/ productivity/

[46] J. B. Dinsmore, K. Swani, and R. G. Dugan, "To 'Free' or Not to 'Free': Trait Predictors of Mobile App Purchasing Tendencies," Psychol. Mark., vol. 34, no. 2, pp. 227-244, Feb. 2017. https://doi.org/10. $1002 /$ mar . 20985

[47] O. T. M. Klos, "Mobile applications, which factors influence the demand for mobile applications across different operating systems in the Netherlands?," Erasmus University, 2015.

[48] T. Franceschin, "China ya es el segundo mercado de aplicaciones a nivel global," Vrainz, december 21th 2016. [Online]. Available: http://www.vrainz.com/ china-esta-cerca-de-convertirse-en-el-prin cipal-mercado-de-aplicaciones-a-nivel-global/

[49] "El Mercado de las Aplicaciones móviles en China," China Briefing News, december 21- 2016. [Online]. Available: http://www . china-briefing.com/news/2012/08/13/ el-mercado-de-las-aplicaciones-moviles-en-\ china.html

[50] C. Z. Liu, Y. A. Au, and H. S. Choi, "An Empirical Study of the Freemium Strategy for Mobile Apps: Evidence from the Google Play Market," in Thirty Third International Conference on Information System, 2012, pp. 1-2.

[51] H.-Y. Ho and L.-Y. Syu, "Uses and gratifications of mobile application users," in 2010 International Conference on Electronics and Information Engineering, 2010, pp. 315-319. https://doi .org/10.1109/ICEIE. 2010.5559869 